\title{
The Historiography of the Front de Liberation du Quebec: Frameworks, 'Identity' and Future Study
}

\author{
Kevin Lee Pinkoski
}

\begin{abstract}
This paper examines the historiography of the Front de Liberation Quebecois within the context of three frameworks, each used to devaluate the FLQ, the idea of separation, its potential support and most importantly, the perspectives of historians who oppose these frameworks. Through an examination of the literature, the FLQ are framed as an attack on British liberalism, an attack on Canadian Unity, or violent in a political climate where such actions were unjustifiable. These understandings work cooperatively together to de-legitimize alternative views on FLQ history, and Quebec independence. I will examine also the benefits in studying the FLQ outside of the tensions of separation and the potential for future study in the history of the FLQ.
\end{abstract}

During the 1960s and 1970s, Quebec was exposed to the potential of its own national identity. The realization of this identity took place through the Quiet Revolution, the creation of the Parti Quebecois, and citizen activism towards the goal of independence from Canada. An example of this activism is the Front de Liberation du Quebec (FLQ), generally characterized as a protesting terrorist group. Terrorism in this sense can be described as a desire to achieve political change by obtaining power through violence in order to right a perceived wrong. ${ }^{1}$ In the case of the FLQ, this violence was most recognizable in the kidnappings of James Cross and Pierre Laporte, culminating in the 1970 October Crisis (which resulted in the enactment of The War Measures Act), the 1969 bombing of the Montreal Stock Exchange, and almost 160 other violent incidents attributed to or claimed by the FLQ, killing a total of eight individuals. ${ }^{2}$ However, the majority of historians do not focus their analysis on the development of violence as a means of political expression within a specific social climate, but rather focus on understanding the FLQ as an attack on Canadian 'values' and 'identity'. This has created three different understandings within the historiography of the FLQ that serve to influence the reader to question the validity of the movement. While these understandings are also theories for explaining FLQ actions, their presence in the literature serves to dissuade support for the FLQ and its independence goals. The first understanding argues that the FLQ was an attack against British individual liberalism. The second argument conceives of the FLQ as an action against Canadian unity. The final argument emphasizes that the FLQ's violent actions took place in a political climate where violence is unjustified. These three frameworks can be seen as the basis for most of the historiography of the FLQ, especially in works written just after the October Crisis. All three frameworks are established by Anglo-Canadian historians, and dominate Anglo-Canadian perspectives. Working cooperatively to de-legitimize alternative views on FLQ history and Quebec independence, these understandings maintain a politicized understanding of the FLQ, connected directly to the development of the separatist movement.

Characterizing the FLQ as an attack against British Liberalism and Canadian unity, as well as describing the organization as violent has been used to both manipulate readers to oppose FLQ

\footnotetext{
${ }^{1}$ James D. Kiras, "Terrorism and Globalization" in The Globalization of World Politics, (ed.) John Baylis, Steve Smith and Patricia Owens (Oxford: Oxford University Press, 2011), 366-367.

2 Judy Torrance, Public Violence in Canada (Montreal: McGill-Queen's University Press, 1988), 37
} 
actions, while at the same time, devaluing other possible narratives. I analyze these three perspectives, and how they pitted the FLQ against the foundations of Canadian society. Second, this paper will prove the existence of these perspectives within FLQ historiography. I explore the effects these three understandings on histories outside, or in contraction to these frameworks. More recent perspectives on the FLQ have moved beyond the fear of Quebec separation as a result of confidence in Canadian unity, and developed a view on the FLQ based specifically on its place within the independence movement as a product of a specific social environment.

\section{Three Perspectives}

\section{An Attack on British Liberalism}

The importance of British liberalism in Canada is clearly defined by historian Ramsay Cook. Cook understands British liberalism as an independent liberalism, where value is placed on homogeneous individuals, instead of minority group rights. ${ }^{3}$ While the increase in non-British immigration has created a heterogeneous community, Cook still believes that British liberal doctrine was used to justify a maintenance of Canada's internal security, even to a diverse community. ${ }^{4}$ Therefore, the response to dissident actions, such as the FLQ, is seen not as a minority group attempting to challenge power structures, but instead, a direct attack on individual liberties. Cook argues that within the French Civil Law tradition, minority and group rights take the main focus over individual rights. ${ }^{5}$ The FLQ can be understood as a specific attack on the individual liberties of every Canada, because they emphasized group rights over individual rights.

Ramsay Cook argues that within FLQ historiography, the group's actions are framed as an attack on British liberalism. It is important then to understand British liberalism as both individual freedom and the freedom to use inherited British institutions. Gerard Pelletier's The October Crisis outlines the role of government within Canadian society. He defines it as the role of an arbitrator to administrate the interests and values of a community. ${ }^{6}$ Pelletier believes that this community is an accumulation of various harmonious and contradictory subgroups. ${ }^{7}$ These subgroups then become active when individuals participate in civil society and democratic processes. ${ }^{8}$ The use of the democratic process, the very Westminster institution inherited from Britain, highlights a key part of British liberalism. This leads Pelletier to argue that the FLQ existed in contrast to not only democratic process, but individual freedom as well, as every individual was at risk within the ambiguity of FLQ targets. As Pelletier proposes, extremists both ignore the existing political tools and find them useless to their goals, so instead attempt only to increase the liberty of their own specific group. ${ }^{9}$ However, by ignoring the existing political tools, an extremist group ignores the foundations of British liberalism heritage in Canada. Violence, therefore, is not a viable form of political protest in Canada, because Canadians have been given the tools of voting, freedom of speech, freedom of press, and freedom of the individual (with certain prescribed and proscribed limits). Violence is both an attack on individual liberties, which the general public must sacrifice as the government ends this violence, and a fracturing of the political power system. ${ }^{10}$ This could, according to Pelletier, result in the end of the

\footnotetext{
${ }^{3}$ Ramsay Cook, "War Measures in Time of War." in Trudeau's Darkest Hour: War Measures in Time of Peace, October 1970 (ed.) Guy Bouthillier and Edouard Cloutier (Montreal: Barabooks, 2010), 30.

${ }^{4}$ Ibid., 33.

${ }^{5}$ Ibid., 33

${ }^{6}$ Gerard Pelletier, The October Crisis (Toronto: McClelland and Stewart Limited, 1971), 30.

${ }^{7}$ Ibid., 31.

8 Ibid.

${ }^{9}$ Ibid., 37.

10 Ibid., 41.
} 
foundations of British liberalism; an "irrational society" would develop where factions would struggle for power, and self-affirmation. ${ }^{11}$ This would end the value of the individual within the political system, as the individuals themselves would be powerless against these factions. The FLQ, through the use of violence, created an unnecessarily radicalized appearance of their protest to the general public. Pelletier cites both the Upper and Lower Canadian Rebellions as examples of violence failing to garner much support and sympathy. He believes that both these rebellions were examples of unrest rejecting existing and effective political structures. ${ }^{12}$ But Pelletier ignores that the political structures were not effective tools for Quebec. Pelletier concludes by claiming that "crisis solves nothing," because it causes the individual to turn to established power structures out of fear for his livelihood. ${ }^{13}$

In a similar fashion, M.V. Naidu argues that the FLQ actions were not the proper use of democratic freedoms, but instead, a direct attack against these established liberties. ${ }^{14}$ Naidu believes that there is a certain respect for 'law and order' in Canada. While these terms might have an association with right wing ideologies (in a neo-liberal sense), in Canada, they are synonymous with individual freedom. ${ }^{15}$ The FLQ, by ignoring democratic means of expression, appeared to be a direct attack on the law and order established in Canada. Naidu claims that this in itself caused Canadians to interpret this as an attack on the foundations of their own society, no matter where they lived geographically. ${ }^{16}$ The FLQ would only be justifiable if they had been able prove that the current system of law and order failed to properly represent their interests. But in failing to do this, Naidu believes that FLQ actions were perceived as an attack on "society itself and its way of life." 17 This way of life is, as Ramsay Cook believes, the inherited values that exist as the foundations of Canadian society. ${ }^{18}$ Naidu believes that the government response was seen as a civil war, a war between popular ideologies and the actions government took against them. ${ }^{19}$

According to Naidu and Pelletier, this sense of civil war was seen as a direct attack on a key foundation of Canadian society. This framework, as established by Cook, takes advantage of a reader who values the Canadian democratic process, and values their own individual liberties. Because of these simplistic beliefs, readers are forced into an automatic criticism of The FLQ, and in some relation, Quebec independence movements, by focusing specifically on the FLQ's infringements towards the Canadian cultural heritage of British liberalism. However, there are other parts of Canadian culture that counter the FLQ goal of independence, specifically the idea of a single, unified Canada.

An Attack on a Unified Canada

The second framework is best explained by historian Jack Granatstein, who argues that FLQ actions were an attack on the idea of a unified Canada. Granatstein describes the anti-FLQ events as a "Rally for Canada," as they were often titled, thereby proving that the FLQ was seen as contesting

\footnotetext{
11 Ibid., 39.

12 Ibid., 42.

13 Ibid., 49.

${ }^{14}$ M.V. Naidu, "Democracy versus terrorism: FLQ terrorism in Quebec, a case study," Peace Research: The Canadian Journal of Peace and Conflict Studies 27 (1995).

15 Ibid.

16 Ibid.

17 Ibid.

18 Ramsay Cook, 31.

${ }^{19}$ M.V. Naidu.
} 
Canada as an entity. ${ }^{20}$ This is most evident in Granatstein's own invitations to "speak on behalf of Canada" at such rallies. ${ }^{21}$ These events created an atmosphere across Canada where all Canadians felt that they themselves were targets merely because they were Canadian, rather than Quebecois, and therefore political action aimed at independence in Quebec was seen as terrorism. ${ }^{22}$ This dichotomy situated Canada against Quebec, where FLQ action was an attack on the idealistic image of Canada. It was an attack on more than just Canada's unity with Quebec, an attack on the unity of the nation as a whole.

Granatstein believes that the immediate response to FLQ violence and the enacting of the War Measures Act created the image of a federal government in support of a unified Canada. ${ }^{23}$ To elaborate on this framework, I will examine how the FLQ's actions have been framed as an attack on Canadian unity. In his book, The October Crisis: An Insider's View, William Tetley specifically focuses on the FLQ as an actor for independence, while ignoring the variety of other goals within the FLQ manifesto. Tetley begins with a fair evaluation, stating that the ultimate goal of both the 1963 and 1970 FLQ was a separate Quebec. ${ }^{24}$ He stresses the reality of this goal in comparison to global independence movements, such as in Cuba and Algeria. ${ }^{25}$ This creates a legitimacy in the FLQ's potential to realize their goals, much like the FLN in Algeria. Tetley proposes that the FLQ was less interested in the minor grievances of the Quebec society, but instead focused on a larger goal. ${ }^{26}$ Tetley cites FLQ member Pierre Schinder, who believed that "in Canada, democracy never existed." 27 Tetley takes advantage of Schinder's admiration of Louis Joseph Papineau, which Tetley believes to be within the same context of a protest for an end to colonial dominance. ${ }^{28}$ However, Tetley critiques Schinder for his admiration, due to the fact that Papineau was in conflict with the British, and he himself did not advocate for violence means. ${ }^{29}$ Therefore, Tetley believes the democracy that the FLQ targeted is in itself a greater Canadian democracy, which has managed to unify the rest of this nation. This differs from Cook's understanding, because it relies on the existence of a larger, culturally diverse group who understand itself as Canadian, instead of an individual who believes in liberalism and the use of that liberalism within political institutions. There is enormous ambiguity in what the term "Canadian" means. According to Tetley, the entire Canadian society was targeted by the FLQ due to its existence within the democratic framework, a symbol of English domination in Quebec. ${ }^{30}$

This sense of polarization is evident in Denis Smith's Bleeding Hearts... Bleeding Country: Canada and the Quebec Crisis. First, Smith cites the reason for Trudeau's 1968 election as an endorsement for "a French-speaking prime minister, who promised to maintain the federal union." 31 Smith believes that this election both suppressed English Canadian discussion of federal reform, and made the system seem flexible and adaptive. ${ }^{32}$ According to Smith, this caused the rest of Canadian society to be

\footnotetext{
${ }^{20}$ Jack Granatstein, “In English Canada," Trudeau's Darkest Hour: War Measures in Time of Peace - October 1970, (ed.) Guy Bouthillier and Edouard Cloutier (Montreal: Barabooks, 2010), 132.

${ }^{21}$ Ibid., 131.

22 Ibid., 134.

23 Jack Granatstein, 133.

${ }^{24}$ William Tetley, The October Crisis: An Insider's View (Montreal McGill-Queen's University Press, 2007$), 18$.

${ }^{25}$ Ibid., 19.

26 Ibid., 21.

27 Ibid.

${ }^{28}$ Ibid.

${ }^{29}$ Ibid.

30 Ibid., 22.

${ }^{31}$ Denis Smith, Bleeding Hearts...Bleeding Country: Canada and the Quebec Crisis (Edmonton, M.G. Hurtig Ltd, 1971), xii.

32 Ibid.
} 
unable to understand why Quebec seemed to be the only province "frustrated by this impasse.",33 The rest of Canada appeared unified behind the idea of federalism, believing that flexibility was a key part of an effective Canadian federalism that had worked for the past 100 years. ${ }^{34}$ This flexibility makes federalism in Canada specifically Canadian, as it had adapted enough to accommodate diverse regions and ethnic minorities. At the same time, Smith argues that the violent actions ignored the tools of deliberation and compromise as they have been historically used in Canada, causing Canadians to feel as if the foundations of their own society are under attack. ${ }^{35}$ The general Canadian public do not see themselves as a violent people, and therefore could only have understood this violence as an attack on their own nation, and the identity they derived from it. As Granatstein cited, the "Rally for Canada" and speaking against the government's actions was understood as "speaking against Canada." 36 There is no doubt that the FLQ was a threat to Quebec as a part of Canada. However, this framework only focuses on a single FLQ goal, ignoring all other demands and objectives, and specifically uses it as an external objective in an attempt to rally support against the movement. This shifts the context of the FLQ as an organization with the goal of a free Quebec to one that believes in a destruction of Canadian society. Suddenly, the FLQ goal includes more than just the population in Quebec; the FLQ targets the very foundation of Canadian values that serve to unify the nation. While independence was an aim of the FLQ, the excessive focus on it served to polarize Canada against the FLQ and separatist sympathizers. Independence was an attack on Canadian society, routing moderate supporters and sympathizers. This focus on the FLQ as a violent group specifically disperses support across all of Canada.

\section{Unjustified Violence}

The final historical framework is best described by historian Desmond Morton, who examines the complexity of support for both the FLQ and Quebec independence. Morton sees the support base of the FLQ as both the small, radicalized groups and the dilettantes of both Quebecois and international independence movements. ${ }^{37} \mathrm{He}$ argues for a focus on the violent actions of the FLQ and the reaction of the Trudeau government, which qualifies the FLQ as radicals without a justifiable cause. The goal of historians who make use of this framework is then to break up the indirect support of Quebec independence, the 'coffee table radicals' who dream not of violent action, but ethnic independence and distinct identity in a global context. ${ }^{38}$

This framework focuses on the violence within the FLQ's actions and aims. This framework differs from the previous two, in that of targeting a large Canadian audience, it specifically aims to dissuade partial supporters of the FLQ and Quebec independence. Morton argues that a history that focuses on the FLQ's violent actions, its public terror, and choice of targets attempts to end its connection with international liberation movements. ${ }^{39}$ By removing this connection, dilettantes in support of the radicalization of the independence movement are, as Morton claims, dissuaded by the justification of these actions. ${ }^{40}$ Louis Fournier portrays this understanding in his book The FLQ: The Anatomy of an Underground Movement. Fournier understands the FLQ as a violent entity, as he specifically cites the more malicious aspects of FLQ propaganda. Fournier briefly summarizes FLQ demands, by stating

\footnotetext{
${ }^{33}$ Ibid.

${ }^{34}$ Ibid.

35 Ibid., xiv.

36 Granatstein, 131.

37 Desmond Morton, "In Hindsight," Trudeau's Darkest Hour: War Measures in Time of Peace - October 1970, (ed.) Guy Bouthillier and Edouard Cloutier (Montreal: Barabooks, 2010), 184.

38 Ibid.

39 Morton, 184.

${ }^{40}$ Ibid.
} 
that the FLQ was a "revolutionary movement" aimed to target all "colonial symbols and institutions." 41 The FLQ was therefore the radicalized wing of the Quiet Revolution's Quebec independence movement. ${ }^{42}$ Fournier creates this radicalized FLQ by considering this independence movement within a global revolutionary context. This allows Fournier to develop an understanding of the potential dangers of the FLQ. The first example Fournier cities is the Algerian successful independence due to its violent armed struggle and bomb networks, which indiscriminately targeted any symbol of French society. ${ }^{43}$ He refers to Frantz Fanon's understanding of violence as a necessary tool to revert the colonial construct of a master-slave relationship. ${ }^{44}$ Then Fournier examines Cuban independence movements, and the relevance of guerrilla warfare against both the military, and symbols of Cuba's imposed national identity. ${ }^{45}$ Finally, Fournier elaborates upon the relevance of Northern Ireland's independence movements. He cites IRA chief of staff Sam Cronin, who believed that only through guerilla warfare, such as violent raids on military institutions, bombings, and armed confrontations could a small nation defeat a superior nation. ${ }^{46}$ From this, Fournier believes that for an independence movement, patriotism and violence are two "indispensable elements, if not in fact the main driving force in all revolutions." ${ }^{47}$ Violence then becomes key to understanding the FLQ, which creates the format of analysis within Fournier's book as he recounts every violent event the FLQ is associated with. However, Fournier connects the FLQ to both the radical and most active wing of the Quebec independence movement, so that the FLQ becomes representative of the Quebec independence movement. ${ }^{48}$

According to Morton's framework, Fournier is outlining violence in an attempt to dissuade moderate FLQ supporters. First, Fournier is questioning of violence as adequate means, as he proposes violence may have polarized Quebecois support. ${ }^{49}$ Second, while he tries to create a global context of violence, he is seemingly critical of the sporadic and unfocused violence ofindependence movements. Fournier includes how Algerian, Cuban, and Irish movements all attacked both military and civilian targets, thus becoming known as terrorists. ${ }^{50}$ The partial supporter is, according to Morton, left to question their own link to a radical movement. While Fournier later explains that the federal government's response towards the FLQ and the October Crisis affirmed the future potential desire for Quebec independence, it developed out of the government's unwillingness to compromise during the Quebec crisis. However, Fournier's understanding of the FLQ dissociates the mild supporter through an emphasis on violence as its only means.

Gustave Mort's Terror in Quebec also views the FLQ as excessively violent. Mort argues that a romantic image of independence ended due to violent confrontation. ${ }^{51}$ The romantic image emerged from both the Quiet Revolution's academic influence on the independence movement and the international context of struggle for sovereignty and nationhood. ${ }^{52}$ To end this romantic image, Mort focuses on the targets of FLQ violence. He uses the example of Vincent Wilfred O'Neill, nightwatchman and victim of the 1963 Recruiting Center bombing, as violence against "a man doing

\footnotetext{
${ }^{41}$ Louis Fournier, The FLQ: Anatomy of an Underground Movement (Toronto: NC Press Limited, 1984$), 14$.

42 Ibid., 16.

43 Ibid., 21.

44 Ibid.

45 Ibid., 22.

46 Ibid., 23.

47 Ibid.

48 Ibid., 29.

${ }^{49}$ Ibid., 27.

50 Ibid. 23.

${ }^{51}$ Gustave Mort, Terror in Quebec (Toronto: Clark, Irwin and Company, 1970), preface.

52 Ibid.
} 
his duty." 53 Mort sees this as an example of the FLQ "going the full way for their crime... [through] the fireworks of hate." ${ }^{54}$ Later, Mort proposes that that the conclusion of the October Crisis employed the same over-excessive use of violence. He believes that the FLQ group that killed Laporte simply escalated a nonviolent situation, most likely through the perversion of excessive drugs and sadism. ${ }^{55}$ Liberation through the means of such unjustifiable violence was in itself an attack on French Canadian values. ${ }^{56}$ This, according to Mort, separated a true understanding of Quebecois nationalism by dishonoring the distinctive values that create the very idea of French Canadian nationhood. ${ }^{57}$ Mort is aware of Morton's understanding, as Mort even proposes that the French Canadian, the Canadian, and the international observer were more than likely to side with the victim. ${ }^{58}$ The separation movement became disenfranchised from popular support through a loss of dialogue containing terms like "people, democracy and peace." ${ }^{59}$ The dilettantes and "coffee shop supporters' of the Quiet Revolution and the initial idea of the FLQ dissociated themselves from the movement due to its expressively violent tendencies. These violent tendencies were seen as unjustifiable and unnecessary. This alienated readers sympathetic to the idea of political equality, but who themselves would not commit nor justify such actions. Morton's perspective, as well as Cookis and Granatstein's understandings, expose how the FLQ actions and the radical end of the independence movement have been portrayed not only as terrorist activities, but as violent actions that attack the idea of justifiable independence, liberal values and finally, Canada itself. The hegemony of their viewpoints has pushed aside perspectives in history that develop outside of these three frameworks with different understandings of FLQ actions.

The three previously explained historical frameworks serve as a unified tool against historical works that attempt to understand the FLQ differently. This historiography makes use of previously established beliefs of Canadian 'identity' and 'values' to refute FLQ actions instead of analyzing the FLQ as a product of a specific political and social climate. This paper does not serve to argue that the FLQ is morally right in its use of violence. However, I argue that a proper FLQ history should develop from an understanding of why violent actions were chosen as a means of expression and why the political and social atmosphere created a situation where they became means of protest. While the historical context is crucial to understanding the FLQ, it can also be limiting. The three previous perspectives do not allow for an elaborated understanding of either the FLQ and dissent in Canada, creating an underdeveloped understanding within FLQ historiography. These perspectives call upon the assumed values for the reader and historian, forcing all those who identify with liberalism, Canadian unity, and non-violence means of expression to reject both the FLQ and Quebec sovereignty. These perspectives can serve as a basis for refuting the justification of these actions, but they do not support the individual understandings of the FLQ members and their own orientation towards Canadian society. These understandings make use of the politicized framework of Quebec independence, treating the FLQ as an active threat the future of Canada. By basing their histories specifically on these perspectives, the historiography of the FLQ refuses to make compromise for alternatives points of view.

\section{Conflicting Narratives}

\footnotetext{
${ }^{53}$ Ibid., 6.

54 Ibid.

55 Ibid., 175.

${ }^{56}$ Ibid., 176.

${ }^{57}$ Ibid., 6.

58 Ibid.

59 Ibid., 176.
} 
Since the historiographical trends above depend on the key foundations of the reader's and historian's identity as 'Canadian', alternative views of the FLQ are devalued. The first example of this can been seen in the conclusions made in Pierre Vallieres's The Assassination of Pierre Laporte. ${ }^{60}$ Vallieres proposes that the actions of Trudeau and his government served to reaffirm Canadian unity, and that Trudeau attempted to frame the FLQ as poised to overthrow Canadian society. ${ }^{61}$ First, Trudeau associated his actions with Canadian unity, a fight for democracy and freedom in Canada, to create a cross-Canadian nationalism that could counter Quebecois nationalism. ${ }^{62}$ Therefore, Valliers believes that FLQ actions were framed to be seen not only as an attack against democracy, but also the framework of the Canadian constitution towards Quebec. ${ }^{63}$ This action created a 'Quebec against the rest' mentality, where 'the rest' identified themselves as 'Canadian.' The War Measures Act was, as Vallier proposes, an action taken to ensure this unity and to give Canadians faith in their federal system, identity and nationhood. ${ }^{64}$ However, because of the amount of written history that supports Granatstein's perspective, Vallieres needed to prove that the FLQ was not attacking Canadian unity as a whole, but specifically Quebec's relationship to Canada. It is worth noting that within the FLQ manifesto, the FLQ claim only to desire Quebec independence, and not a destruction of Canada. ${ }^{65}$ However, this is not to say the separation of a distinct society would not destroy the unity of Canada.

The perspective that the federal government infringed on Canadian civil liberties with the War Measures Act is a second example of a narrative in conflict with the idea of the FLQ attacking liberalism and Canadian unity. This perspective, as proposed by Dominique Clement, argues that the War Measures Act was responsible for the violations of human rights across the country. ${ }^{66} \mathrm{Clement}$ cites illegal actions committed by the RCMP, as they sifted through mail, distributed false communiqués and raided politicians' offices. ${ }^{67}$ Clement's argument is based in an understanding of civil rights, but comes into conflict with Cook's British liberalism, which justifies the infringement of civil rights to maintain individual rights, such as private property and individual liberty, within a democratic process. ${ }^{68}$ This debate is less straight forward, as many readers may either not understand the complexity of these different types of liberty or they might include civil rights as a key part of their personal liberty. However, British liberalism's integration in democratic institutions and the attempt to act for 'the majority' justifies RCMP actions due to the state of potential conflict and potential threat against the individual.

David Charter understands the FLQ as an amateur revolutionary movement, contradicting Morton's emphasis of the FLQ as a violent movement. Charter believes that the FLQ did not attempt to connect itself to an international context, due to the FLQ's failure to justify a colonial situation. ${ }^{69}$ Charter argues that poor coordination and organization led to logistical failures due to financial considerations, which downplayed the group's ability to use symbolic means of expression. ${ }^{70}$ While

\footnotetext{
${ }^{60}$ It should be noted that Valliere himself is a contested figure, due to his active involvement with FLQ.

${ }^{61}$ Pierre Valliere, The Assassination of Pierre Laporte (Toronto, James Lorimer \& Company, 1977), 21.

62 Ibid., 24

${ }^{63}$ Ibid.

${ }^{64}$ Ibid., 26.

${ }^{65}$ Le Front du Liberatation de Quebec. "Manifesto,” 1970.

${ }^{66}$ Dominique Clement, "The October Crisis of 1970: Human Rights Abuses Under the 'War Measures Act," Journal Of Canadian Studies 42, no. 2 (2008), 161.

${ }^{67}$ Ibid., 176.

${ }^{68}$ Shaun Young, Beyond Rawls: an analysis of the concept of political liberalism (Lanham: University Press of America, 2002), 30.

${ }^{69}$ David A. Charters, "The Amateur Revolutionaries: A Reassessment of the FLQ," Terrorism \& Political Violence 9, no. 1 (1997), 134.

${ }^{70}$ Ibid., 142.
} 
Charter cannot deny that there were violent actions, his attempt to downplay their significance suggests that historians overemphasize the violence commuted by the FLQ. However, the three frameworks work cooperatively to refute alternative perspectives. I argue that a reader, specifically a Canadian reader, is more likely to agree with the historical argument of British liberalism, Canadian unity, and a dislike of violence, and remain unable to understand the exact actions of the FLQ as compared with sweeping national values and ideas.

\section{Alternative Narratives}

There are historical works that exist outside of the conflict that is created around these three perspectives. These benefit from ignoring the direct potential for Quebec separation; they do not attempt to counter the FLQ movement, but simply understand it. The first example of this is Jane Jacobs' 1980 monograph, The Question of Separatism: Quebec and the Struggle over Sovereignty. Jacobs is aware current perspectives are influenced by emotions, where both the Quebec separatists and greater Canadian public are influenced by a sentiment of national identity. ${ }^{71}$ Because of this, Jacobs believes that a sense of rationality is lost, as the FLQ and Quebec independence movement works against the emotions present in a national Canadian identity. ${ }^{72}$ Jacob attempts to separate her work from previous perspectives on the FLQ by understanding where the FLQ fits within the independence movement and Quebec society. According to Jacobs, there are two influential circumstances that lead to the creation the FLQ. She holds that FLQ was a product of a specific Quebecois mentality that developed out of an "English assumption of superiority over industry, commerce, and public works... threatening [the Quebecois] with a loss of identity." 73 However, she also understands the FLQ as a product of the Quiet Revolution, which failed to address the diversity of goals within Quebec. ${ }^{74}$ She suggests that violence was a means for the FLQ to express their own desperation and support for sovereignty to Quebec's people. This created a sense of desperation for the FLQ to find a greater role within the Quebec independence movement, attracting those Quebecois who felt the Quiet Revolution addressed them but did not include them in its discourse.

Trudeau's Darkest Hour: War Measures in Time of Peace October 1970 is a collection of essays that both exposes the three frameworks this paper has used, while at the same time creates a rigorous understanding of the FLQ and Canadian society before, during, and after the October crisis. The book itself benefits significantly from separate portions on the FLQ, Canadian public opinion and the federal government's actions. The conclusion offers critique of past understandings of the series of events. Editors Guy Bouthlier and Edouard Cloutier conclude that early perspectives on the FLQ were focused on 'framing the enemy'. ${ }^{75}$ Broadly defined, the enemy was any person who "advocated, promoted, or engaged in the use of force...as means of government change in Canada." "76 The framed enemy also began to include the longevity of the Quebecois Independence movement. ${ }^{77}$ This movement persisted through the 1980s and 1990s, climaxing with the 1995 Referendum, and attempted to include Quebec within Canada's new constitution. After this point, historians such as Bouthlier and Cloutier became confident in the longevity of Canadian society, and critiqued the past historiography of the FLQ as highly influenced by a counter-separation movement. The recent

\footnotetext{
${ }^{71}$ Jane Jacobs, The Question of Separatism: Quebec and the Struggle over Sovereignty (New York: Random House, 1980.) 3.

${ }^{72}$ Ibid., 4.

73 Ibid., 8.

${ }^{74} \mathrm{Ibid}$.

${ }^{75}$ Guy Bouthlier and Edouard Cloutier, "Conclusion" in Trudeau's Darkest Hour: War Measures in Time of Peace-October 1970

(Montreal: Barabooks, 2010). 197.

${ }^{76} \mathrm{Ibid}$.

77 Ibid., 199.
} 
dormancy in the independence movement has allowed for new perspectives and understandings of the FLQ to emerge. This will only be solidified by the near disappearance of the Bloc Quebecois from federal politics in 2011 and the provincial decline of the Parti Quebecois. These new narratives develop a better understanding of the FLQ, the independence movement, and the reasoning behind these actions. They develop a more elaborate understanding of the role the FLQ saw for themselves within the independence movement, why individuals were attracted to the movement, and the future role of the FLQ in their ideal of an independent Quebec society.

\section{Conclusion}

The early historiography of the FLQ frames the group as an excessively violent attack on British liberalism and Canadian unity which originally served to dissuade the potential support and justification of FLQ actions. However, it denied alternative historical perspectives, and focused on the politicized FLQ within a Quebecois independence framework. Instead of focusing on FLQ actions within the context of the society that produced them, and then passing judgment, they are seen as wrong because they target the very basis and fundamentals of Canadian existence by attacking Canadian 'values'. However, these frameworks were created under the influence of the political question of Quebecois independence, during which Anglo-Canadian historians attempted to bolster the federalist cause. However, in recent years as the political question of Quebec separation became dormant, the potential for new perspectives is more prominent. The FLQ is closer to being understood on historical grounds, instead of within a politicized framework that manipulates the reader to a certain disparaging understanding of the FLQ. 


\section{Bibliography}

Bouthlier, Guy and Cloutier, Edouard. "Conclusion" in Trudeau's Darkest Hour: War Measures in Time of Peace October 1970. Montreal: Barabooks, 2010.

Cook, Ramsay. "War Measures in Time of War." In Trudeau's Darkest Hour: War Measures in Time of Peace October 1970. Edited by Guy Bouthillier and Edouard Cloutier. Montreal: Barabooks, 2010.

Fournier, Louis. The FLQ: Anatomy of an Underground Movement. Toronto: NC Press Limited, 1984.

Granatstein, Jack. "In English Canada.” In Trudeau's Darkest Hour: War Measures in Time of Peace - October 1970. Edited by Guy Bouthillier and Edouard Cloutier.

Jacobs, Jane. The Question of Separatism: Quebec and the Struggle over Sovereignty. New York: Random House, 1980.

Kiras, James D. "Terrorism and Globalization" in The Globalization of World Politics. Edited by John Baylis, Steve Smith and Patricia Owens. Oxford: Oxford University Press, 2011.

Mort, Gustave. Terror in Quebec. Toronto: Clark, Irwin and Company, 1970.

Morton, Desmond. "In Hindsight.” In Trudeau's Darkest Hour: War Measures in Time of Peace - October 1970. Edited by Guy Bouthillier and Edouard Cloutier. Montreal: Barabooks, 2010.

Naidu, M.V. "Democracy versus terrorism: FLQ terrorism in Quebec, a case study." Peace Research: The Canadian Journal of Peace and Conflict Studies 27 (1995).

Pelletier, Gerard. The October Crisis. Toronto: McClelland and Stewart Limited, 1971.

Smith, Denis. Bleeding Hearts...Bleeding Country: Canada and the Quebec Crisis. Edmonton, M.G. Hurtig Ltd, 1971.

Tetley, William. The October Crisis: An Insider's View. Montreal McGill-Queen's University Press, 2007.

Torrance, Judy. Public Violence in Canada. Montreal: McGill-Queen's University Press, 1988.

Valliere, Pierre. The Assassination of Pierre Laporte. Toronto, James Lorimer \& Company, 1977. 